\title{
Journal of Management Sciences
}

Managing Organizational Effectiveness through Talent Management and Career Development: The Mediating Role of Employee Engagement

\section{Affiliation:}

Zulqurnain Ali

School of Management, University of Science and Technology of China, Hefei. Email: zaki.qasms.qau@gmail.com

Madeeha Bashir

The Tips College of Commerce and Business Administration, GC University Faisalabad. E-mail: madeehabashir07@gmail.com

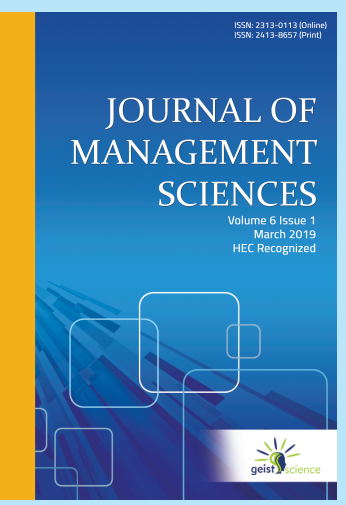

Aqsa Mehreen

School of Public Affairs, University of Science and Technology of China, Hefei.

\section{Manuscript Information}

Submission Date: February 27, 2019

Acceptance Date: April 10, 2019

Citation in APA Style:

Ali, Z., Bashir, M., Mehreen, A. (2019). Managing Organizational Effectiveness through Talent Management and Career Development: The Mediating Role of Employee Engagement, Journal of Management Sciences, 6(1), 62-78.

DOI: https://doi.org/10.20547/jms.2014.1906105 


\title{
Managing Organizational Effectiveness through Talent Management and Career Development: The Mediating Role of Employee
}

\section{Engagement}

\author{
Zulqurnain Ali $^{*} \quad$ Madeeha Bashir $^{\dagger} \quad$ Aqsa Mehreen ${ }^{\ddagger}$
}

\begin{abstract}
Considerable research has performed to link the individual development strategies into organizational performance, but less is known about the role of talent management and career development in enhancing the organizational effectiveness. In the current study, we investigate how talent management and career development direct or indirect effect organizational effectiveness. Moreover, the present study also pursues to test the mediating role of employee engagement in the association between talent management and organizational effectiveness, and career development and organizational effectiveness. Using the survey method, data was collected from permanent employees of commercial banks and the proposed model was tested through structural equation modeling in AMOS. The results suggest that talent management has a substantial effect on employee engagement and organizational effectiveness. Career development has a significant effect on employee engagement and organizational effectiveness. Moreover, employee engagement significantly mediates the relationship between individual development practices (talent management and career development) and organizational effectiveness. The present study guides the bank's management to focus on individual development practices and offer development opportunities to their employees for creating competitive advantage and boosting organizational performance. Finally, the study implications and future research directions are discussed.
\end{abstract}

Keywords: Talent management, employees engagement, career development, organizational effectiveness.

\section{Introduction}

Businesses exist to attain high productivity in their working styles and produce competitive edge in the global economy. To achieve this edge and high efficiency, firms need talented and engaged employees. The role of human resource management becomes even more important than ever in this competitive era. Therefore, talent management (TM) is handling the aptitude, mastery, and vigor of employees inside an organization.TM supports the process of recruitment and evolves the people skills to fulfill the human needs of an organization. The main areas of TM include recruiting, selecting, onboarding new employees, performance management, career development and employee engagement

\footnotetext{
*School of Management, University of Science and Technology of China, Hefei. Email: zaki.qasms.qau@gmail.com

${ }^{\dagger}$ The Tips College of Commerce and Business Administration, GC University Faisalabad.

E-mail: madeehabashir07@gmail.com

${ }^{\ddagger}$ School of Public Affairs, University of Science and Technology of China, Hefei. Email: aqsaali0092@gmail.com
} 
(Romans \& Lardner, 2005; Schweyer, 2010). A study shows that the singlemost significant challenge in human resource is to create their company's ability to compete for talent. Considerable studies have done to link the talent management to the individual as well as organizational performance, but little is known about the role of talent management in enhancing the employee engagement.

The concept of talent management was first originated in the 1980's and 1990's. Companies are now moving from a reactive to proactive approach for obtaining better results from the available human capital. Talent management consists of personals having the best KSA's (knowledge, skills, and abilities). In the ancient ways, organizations believed that having the best people is one of the most essential elements for running an organization smoothly but as the time moves on, organizations realized that having the precise (right) talent is the most key factor to be considered. Gupta (2008) indicated that in the era of competition, every entrepreneur needs to be aware of the current business trends and it can be efficiently handled if the organizations have talented employees. Talent management is getting famous as an important sign of employee and business performance. It means to gain newly capable, experienced and qualified employees to work for the organization as well as developing and retaining existing ones. The assets of a company (machinery, technology) may be replicated easily but the only asset that takes time to change is the Human Asset. It takes much time to develop and considered as the most valuable asset to manage. It is difficult to locate, purify talent and quite easy to lose it. In today's world, it is much difficult to find employees who remain with the organization for more than five years. Thus, companies should make such efforts to develop and manage talented employees. Talent is something that is high on demand. It is a business strategy that merely means "protect or care for the people who keep you in business". In essence, talent is a driver to move the organization where it wants to be.

Literature shows that talent management has a significant effect on the individual as well as organizational outcomes. To our knowledge, the past literature did not explain the relationship of talent management, career development and employee engagement with organizational effectiveness. Therefore, to bridge this gap, the present study intends to develop a framework which guides the bank's management to enhance their performance by providing individual development opportunities. The second goal of this research is to investigate the mediation mechanism of employee engagement in the relationship between talent management, career development, and organizational performance. The motivation to undertake this study is that every organization wants to achieve its goals by using their resources at optimal level and the organizations can achieve its best performance by developing their human resources. Talent management and career development are those significant practices which enhance the level of employee engagement which subsequently increases the organizational effectiveness. Therefore, the present study made an attempt to achieve best organizational performance through employee development practices.

The primary contribution of this paper is to extend the existing body of knowledge by empirically establishing the connection between individual development practices (talent management and career development) and organizational effectiveness which was largely ignored in the area of human resource development. Secondly, the current study 
explains the mediation process of employee engagement in the relationship between talent management and organizational effectiveness. Third, this study helps the bank's management to provide development opportunities to their employees for enhancing their engagement level which subsequentlyimproves the organizational effectiveness. Fourthly, the present study successfully responds to the future call for research made by De Vos and Dries (2013); Lyria, Namusonge, and Karanja (2017). They developed talent management model and theoretically conducted the individual development strategies and their outcomes.

\section{Literature Review}

\section{Talent Management}

Talent management refers to the anticipation of required human capital for an organization and the planning to meet potential needs. It is the art of using premeditated human resource planning to look up business worth and to make it feasible for companies and organizations to get in touch with their goals. Everything was done to take on, hold, build up reward and make people act, forms a part of talent management as well as strategic personnel planning. A talent Management strategy should link to business strategy to function more. The concept mainly deals with human capital that is composed of people, knowledge, and skill. With the use of talent management practices firm's changes the way of using their technology, allocation of available resources and measure performance outcomes. The approach of engaging, developing, motivating and holding of right talent is highly on demand to get the more effective product. Organizations should design such talent management programs that are relevant to their employee's talent and their future needs of the organization. Moreover, organizations should promote a friendly environment in which work effort is organized (Kock \& Ellström, 2011). Organizations should promote such types of systems and procedures that allow them to know about the demanding talent. For the implementation of this process, companies need to know about the existing and potential talent that is needed (Nilsson \& Ellström, 2012).

\section{Career Development}

Career development is the enduring route of managing knowledge, effort, freedom, and evolution to move toward a personally resolute and developing preferred future. Career development is the use of pre-planned instructions to encourage learning $(Z$. Ali \& Mehreen, 2018). This process not only benefits the employee but the organization also. The purpose of career development is to match the employee's aspirations with the firm's challenges that could result in organizational effectiveness. Organizations that want to attract, motivate and retain employees, they need to show concern towards employee career development. History shows that the organizations that support their employees in this regard have experienced the success (Renee \& Bradley, 2007). Organizations play considerable role in the development of their employees. It positively affects an employee career. 
Counseling sessions are of great help to the employees to develop themselves because it provides a path towards achieving career goals. If the organizations arrange training sessions by investing in their employee's career, then the organization in return get the most talented and satisfied workforce (Saeed et al., 2013).

\section{Employee Engagement}

The extents to which employees feel obsessive about their jobs are loyal to the organization, and put unrestricted exertion into their work. Engagement is not just job satisfaction and retention in the company,but it is much more over this phenomena. Engaged employees work with their full physical, mental and emotional energy level. These employees have a strong type of bond with their jobs and feel empowered within the surroundings of the workplace. Kahn (1990) explained employee engagement as "the harnessing of organization member's selves to their work roles in engagement, people employ and express themselves physically cognitively and emotionally". Kahn derived three components from this definition; the Head (cognitive), the Heart (emotional) and the Hand (physical). Companies having engaged employees are prevailing in a win-win situation. They work in a meaningful way, and the results are much better. More engaged human capital in an organization is a sign of a strong organization despite its dimension and locality (Rama, 2009).

\section{Theoretical Background and Hypothesis Development}

The theoretical framework of the study is developed through the Deloitte Talent Management Model that consists of three major components, and they are Develop-DeployConnect. The model is known as the DDC Model. The Model DDC component consists of capacity, commitment, and alignment. These components should be at the core of every organization for the effective success (De Vos \& Dries, 2013). The main theme of DDC model is to develop their employees through proper training, deploy them towards the work they love to do and connect them with the people they want to work with to achieve the maximum level of satisfaction. Through the Development of employees means that organizations should let their employees do every task in a practical way not only a classroom type scenario. The reason of this is to know about the employee's caliber and engagement level. Deploying means how well an organization is getting the benefit of employee's KSA. The main purpose of deploying is to design the job according to employee capabilities that enhance the level of engagement towards work. The third element in the proposed model is to connect the employees with the tools and techniques needed for the completion of the task and also with the people who guide them. The whole process is inter-related. A change in one element leads to affect the others as well. DDC model comprises of three main interests. The first component is capacity that means when talented and capable employees work together; an organization's success is a must. This act leads towards organizational success, and in future, it leads towards career growth. The second component is known as the alignment that is putting the right person on the right 
job with the right skills. The last one is commitment. The central idea is that employees tend to do work with much ease and confidence if it is according to their tastes. DDC model summarizes that organizations need to develop their employees, even more, to get the most out of their engagement and for the sake of organizational effectiveness. Organizations should invest in their employee's career by giving them training opportunities that benefit both the employee and the organization as well. The theoretical framework is showing the proposed relationship of variables. As if the organization retains its talented employees with their career development strategies, it enhances their engagement and results in organizational effectiveness (Deloitte, 2004).

\section{Talent Management and Organizational Effectiveness}

Talent management is a further struggle by the HR maestro to intensify their standards and status. Talent management is said to be a new area of management to stay competitive and differentiable. The history reveals that there are other concepts of leading recently introduced term Talent management as personnel management, HRM, and strategic HRM. So in this sense, we cannot say that talent management is old wine in new bottles as it is a new management ideology and its concepts are quite different from the previous ones (Chuai, Preece, \& Iles, 2008). Researchers proposed a ratio of talent management strategy development as 70:20:10. They thought that $70 \%$ of talent development takes place via working affairs, $20 \%$ passed by relationships and the remaining $10 \%$ is concerned with general development activities (Garavan, Carbery, \& Rock, 2012). In this age of globalization, it is necessary to give attention to know about the right talent of employees for effectiveness (Z. Ali \& Mehreen, 2018). The study shows that if talent management programs are conducted and evaluated rightly than the process of talent management strategy becomes much easy (Abbasi, Sohail, \& Syed, 2010). Adil (2014) mentioned that leader's change-promoting behavior has a significant effect on worker readiness for change which subsequently enriches organizational culture and improves firm performance.

Talent management system should apply to overall all human resource management functions. Having the right talent is the greatest benefit for every enterprise (Z. Ali \& Mehreen, 2018). One of the major roles of HR is to make sure that employee with right skills and talent should stick with the organization for a greater length of time (Ifeoma, Purity, \& Okoye-Nebo, 2015). Talent management is getting popularity as a tool for employees and organizational performance (Kimani \& Waithaka, 2013). The process of talent management fortifies that the member of the workforce is increasing their working output for the prosperity of the firm (Lyria et al., 2017) . In this competitive era, it is quite difficult to retain talented employees because of high mobilization of employees from one organization to the other (Kehinde, 2012). It can be minimized if companies put great effort in engaging employee activities and career development of their employees (Lockwood, 2006). Q. Ali and Brandl (2017) theoretically studied HRM perspectives in Pakistan and found that talent management practices create the competitive advantage which subsequently improves organizational effectiveness. TM is now an important concept that needs attention. Companies need to concentrate on their competitors and their core competencies (Sharma, Garg, \& Singh, 2012). 
Hypothesis 1a: Talent Management is positively related to Employee Engagement.

Hypothesis 1b. Talent Management is positively related to Organizational Effectiveness.

\section{Career Development and Organizational Effectiveness}

The development of an employee's career is a sort of requirement that is important for a shape of social order. It is a continuous process that gives an employee the set of new skills and brightens the existing ones. Now day's employees are more conscious about their professional and personal growth. Organizations that fail to accommodate their employees, they eventually lost their talented workers. A career is something beyond a job. The worker is much more concerned about his/her career and personal development and transformation throughout his work life. Best human resource departments are providing their employees the manager's help within their relevant department. In this era of rapid development employee and manager both need to co-operate to deal with the problem (Zheng \& Kleiner, 2001).

The study focuses on the organizational role that it plays in supporting their personals' career gratification, in fact, it turns out important to appraise the individual's role in their career success, and the individualistic career management is under a great consideration from the last few years. There are some differences between individual and organizational career satisfaction levels, and that differences will leads to a brief understanding of their relationship among them. It also provides the opportunity to mix the two different aspects pledged by (operative-focused) occupational philosophy and (principal-focused) managerial philosophy (Lent \& Brown, 2006). Zafar, Farooq, and Quddoos (2017) highlighted that protean career orientation has a significant effect on perceived employability. While Jan (2010) studied the career development in learning organizations. The study determines the impact of an organizational role in individual capacity development. For this, they used different models to study the impact. The important model was Singe's Learning Organization Model. In this model, five concepts were focused (Personal opinions, mental states, group building, collaborative vision and System thinking) (Guest, 2014).

Hypothesis 2a. Career Development is positively related to Employee Engagement. Hypothesis $2 b$. Career Development is positively related to Organizational Effectiveness.

\section{Employee Engagement and Organizational Effectiveness}

Effective talent management policies and practices are those who show commitment to employees, and this step automatically leads to lower turnover rates and high engagement of employees and it directly affects organizational productivity and success. Employee engagement can be the hot issue because engaged employees perform $20 \%$ better than other employees and ultimately their turnover chances are far less. Some kinds of benefits associated with the workforce also enhance engagement towards work. It is a challenge for HR to strengthen workforce engagement. Organizations should provide a 
sense of regard and honor to the employees. Organizational culture and values are also responsible for the enhancement and decreasing of employee engagement. Managers must ensure an environment in which the workforce become occupied as a cognitive personality, as well as emotionally attached and they are also provided by the information needed and the feedback of their task (Fred \& Suzanne, 2002). Kahn (1990) stated that it is an individual's internal calculus that they consciously or unconsciously make to show their different dimensions in the organization. It is the employee's own perception that how to see and react to the things around. Employee engagement is exactly consequential if there is a sense of giving out the responsibilities between the management and the workforce. The entire workforce has not the same level of commitment towards the work and the organization. If an employee who is highly engaged in emotions he needs to be well aware of all the information needed about the organization. Similarly, a cognitive personality in an organization needs to access the whole information to achieve organizational goal. Both the employees are engaged, but they differ in their approach to make it worthy (Kular, Gatenby, Rees, Soane, \& Truss, 2008).

Hypothesis 3. Employee Engagement is positively related to Organizational Effectiveness.

Hypothesis 4.Employee engagement positively mediates the relationship between talent management and organizational effectiveness.

Hypothesis 5. Employee engagement positively mediates the relationship between career development and organizational effectiveness.

Figure 1

Proposed Empirical Model

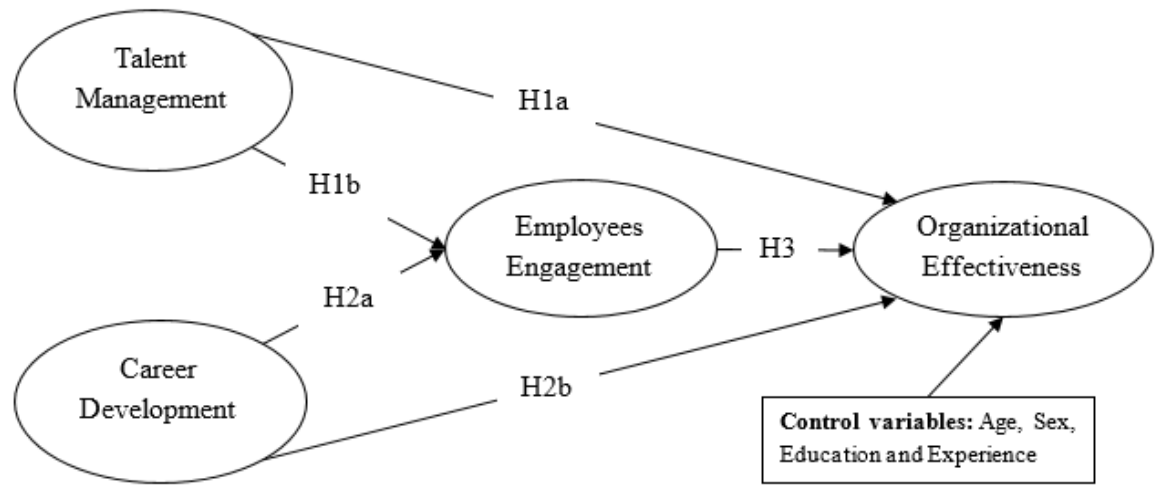

Figure 1 demonstrates the diagram of the proposed model and relationships between 
the predictors and criterion variables for the better understanding of the structural relationships.

\section{Methodology}

\section{Sample and Procedures}

The participants were permanent workers of retail bank branches and recruited from a large district of Pakistan. Participants belong to the different department of the branch banking networks such as sales, operations, cash, and insurance. Initially, the first author contacted the branch managers of different banks over the telephone and briefed about the purpose of the study. They were requested to participate in the study while completing a questionnaire and ensured them their responses would not be misused by any means. They were agreed to participate in the study and demanded that the results of the study will be shared with them. After obtaining willingness to fill out the questionnaire, a sum of five hundred questionnaires was distributed among bank branches. Before sending the questionnaire to participants, a pilot study consisted of thirty-five employees was carried out to check the understandability of the participants about questionnaire items. The findings revealed that nobody report any confusion responding to the questionnaire items.

\begin{tabular}{|c|c|c|}
\hline Characteristics & Freq & Percent \\
\hline \multicolumn{3}{|l|}{ Gender } \\
\hline $\begin{array}{l}\text { Male } \\
\text { Female }\end{array}$ & $\begin{array}{l}195 \\
105\end{array}$ & $\begin{array}{l}65 \\
35\end{array}$ \\
\hline \multicolumn{3}{|l|}{ Age } \\
\hline $\begin{array}{l}16-25 \\
26-35 \\
36-45 \\
\text { Above } 45 \\
\end{array}$ & $\begin{array}{c}60 \\
183 \\
48 \\
9 \\
\end{array}$ & $\begin{array}{c}20 \\
61 \\
16 \\
3 \\
\end{array}$ \\
\hline \multicolumn{3}{|l|}{ Education } \\
\hline $\begin{array}{l}\text { Bachelor } \\
\text { Master }\end{array}$ & $\begin{array}{l}159 \\
141 \\
\end{array}$ & $\begin{array}{l}53 \\
47\end{array}$ \\
\hline \multicolumn{3}{|l|}{ Experience } \\
\hline $\begin{array}{l}0-2 \\
3-5 \\
6-10 \\
\text { Above } 10\end{array}$ & $\begin{array}{c}72 \\
90 \\
105 \\
33\end{array}$ & $\begin{array}{l}24 \\
30 \\
35 \\
11\end{array}$ \\
\hline
\end{tabular}

Furthermore, the questionnaire was checked by two seasoned bankers and one university teacher, and their comments and suggestions were incorporated in the current form of the questionnaire to improve the readability and understanding of the questionnaire. After the continuous follow-up, we received back 233 questionnaires, and four questionnaires were discarded due to the inappropriate filling. We have 229 questionnaires adequately filled by the participants with a response rate of 45.8 percent to conduct the further anal- 
ysis. Table 1 shows that most of the participants were male (195) as compared to female (105). About 53 percent of the participants hold bachelor degree followed by 47 percent holds a master degree. Majority of the respondents fall in the age bracket of 26 years to 35 years and have 6-10 years of experience in working at banks.

\section{Measures}

The present study attempted to explore the relevant past studies to ensure the content and face validity of the adapted measures. The scale of talent management (four items) was taken from the study of De Vos and Dries (2013). The scale of career development (four items) was adapted from the research work of Langley, Du, and Herbst (1992). The scale of employee engagement (four items) was taken from the findings of Schaufeli and Bakker (2004). Similarly, the scale of organizational effectiveness three items) was adapted from the research work of Quinn and Rohrbaugh (1981). Consistent with the past studies on organizational effectiveness, the current study employed the demographic characteristics as control variables to assess their influence on criterion variable (i.e., organizational effectiveness).

\section{Data Analysis}

To test the proposed model and structural hypotheses, the present study employed structural equation modeling (SEM) in AMOS 24.0 version. The reason to run SEM in AMOS is that AMOS is a powerful software which simultaneously performs factor analysis (CFA: measurement of the model) and regression analysis (Path analysis: structural model). Before performing the main analysis, the sample set was checked for the potential issue of outliers, missing values and multicollinearity $(\mathrm{VIF}<10$ and Tolerance $=0-1)$. The findings did not show any issue in the sample set.

\section{Results}

Table 2 shows the descriptive statistics, the outcome of inter-correlation and values of the square root of average variance extracted (AVE). As expected, talent management significantly correlates with employee engagement $(\mathrm{r}=.594, \mathrm{p}<.01)$ and organizational effectiveness $(\mathrm{r}=.528, \mathrm{p}<.01)$. Similarly, career development significantly correlates with employee engagement $(\mathrm{r}=.342, \mathrm{p}<.01)$ and organizational effectiveness $(\mathrm{r}=.486, \mathrm{p}<.01)$. Moreover, employee engagement positively and significantly correlates with organizational effectiveness $(\mathrm{r}=.563, \mathrm{p}<.01)$. All these outcomes illustrate the initial acceptance of proposed structural relationships for the current study. 
Table 2

Descriptive Statistics, Reliability and Correlation matrix

\begin{tabular}{llllllllll}
\hline Constructs & Mean & SD & Alpha $(\alpha)$ & CR & AVE & $\mathbf{1}$ & $\mathbf{2}$ & $\mathbf{3}$ & $\mathbf{4}$ \\
\hline 1 TM & 3.792 & 0.5978 & 0.757 & 0.8127 & 0.5228 & $\mathbf{0 . 7 2 3}$ & & & \\
2 CD & 3.740 & 0.6442 & 0.797 & 0.8123 & 0.5224 & $.438^{* *}$ & $\mathbf{0 . 7 2 3}$ & & \\
3 EE & 3.658 & 0.6266 & 0.800 & 0.8008 & 0.5018 & $.594^{* *}$ & $.342^{* *}$ & $\mathbf{0 . 7 0 8}$ & \\
4 OE & 3.720 & 0.5556 & 0.775 & 0.7973 & 0.5676 & $.528^{* *}$ & $.486^{* *}$ & $.563^{* *}$ & $\mathbf{0 . 7 5 3}$ \\
\hline ** Significant at $\mathrm{p}<.01$ and * & *ignificant at $\mathrm{p}<.05$. Diagonal italics are the square root of AVE. \\
CR= Composite Reliability. AVE= Average Variance Extracted.
\end{tabular}

\section{Measurement Test}

By following the guidelines of Rogelberg and Stanton (2007), the present study conducted a t-test to assess the potential issue of non-response bias by comparing the early $(n=30)$ and late $(n=30)$ participants. The findings of the $t$-test revealed an insignificant difference between both group ( $\mathrm{p}>.05)$, thereby representing that non-response bias was not exist in the current study. Furthermore, the present study evaluated the potential issue of common method bias (CMB) by following the guidelines of Podsakoff, MacKenzie, Lee, and Podsakoff (2003). First, we linked the common latent factor (CLF) with the original measurement model in CFA, AMOS. The findings did not depict the significant loss in the loadings of the factors, and CFA estimates remained significant at $p<.05$. Second, the common variance shared between CLF and observed variables were less than fifty percent, thereby representing that $\mathrm{CMB}$ was not a concern for this study. Third, $\mathrm{CMB}$ exists if the values of inter-correlation higher than .90. Table 2 shows that there is no higher correlation between study constructs (Pavlou \& El Sawy, 2006). Thus, all these findings illustrate that $\mathrm{CMB}$ did not exist in the present study.

Convergent validity was checked by analyzing the values of Cronbach's alpha, composite reliability (CR), factor loadings and average variance extracted (Hair, Sarstedt, Ringle, \& Mena, 2012). Table 2 states that the values of Cronbach's alpha range from .75 to 80 , which is higher than .70 of threshold criteria. The values of CR and AVE range from .79 to .81 and .50 to .56 respectively, indicating that successfully achieve the acceptable level of .70 and .50. Furthermore, the factor loadings of all variables items are higher than the threshold level of .60 (see Table 3). All these findings are indicating the solid convergent validity of the research instrument. Furthermore, the present study also evaluates the discriminant validity of the adapted research scales by following the approach of Fornell and Larcker (1981). As per their approach, we compared the square root of AVE with the values of correlations. Table 2 depicts that values of the square root of AVE for each variable are higher than the values of correlations for each variable, thereby indicating that discriminant validity does not exist in this study.

To validate the proposed model, the current study runs the confirmatory factor analysis (CFA) in AMOS 24.0. We linked the four variables (talent management, career development, employee engagement and organizational effectiveness) with each other. The findings of CFA depict that the measurement model is a good fit and acceptable and achieved the threshold criteria of model acceptance suggested by Hair et al. (2012). Table 3 shows that all items estimates are significant at $p<.05$. Furthermore, the model fit indices suggest a good fit to the dataTo validate the proposed model, the current study 
runs the confirmatory factor analysis (CFA) in AMOS 24.0. We linked the four variables (talent management, career development, employee engagement and organizational effectiveness) with each other. The findings of CFA depict that the measurement model is a good fit and acceptable and achieved the threshold criteria of model acceptance suggested by Hair et al. (2012). Table 3 shows that all items estimates are significant at $\mathrm{p}<.05$. Furthermore, the model fit indices suggest a good fit to the data (see Table 4).

Table 3

Confirmatory Factor Analysis

\begin{tabular}{|c|c|c|}
\hline Variables & Paths & Loadings \\
\hline Talent Management & $\begin{array}{l}\text { TM1<- Talent Management } \\
\text { TM2<- Talent Management } \\
\text { TM3 }<\text { - Talent Management } \\
\text { TM4<- Talent Management }\end{array}$ & $\begin{array}{l}0.800 \\
0.769 \\
0.615 \\
0.694\end{array}$ \\
\hline Career Development & $\begin{array}{l}\text { CD1 <- Career Development } \\
\text { CD2 <- Career Development } \\
\text { CD3 <- Career Development } \\
\text { CD4 <- Career Development }\end{array}$ & $\begin{array}{l}0.691 \\
0.826 \\
0.755 \\
0.600\end{array}$ \\
\hline Employee Engagement & $\begin{array}{l}\text { EE1 <- Employee Engagement } \\
\text { EE2 <- Employee Engagement } \\
\text { EE3 }<- \text { Employee Engagement } \\
\text { EE4 }<- \text { Employee Engagement }\end{array}$ & $\begin{array}{l}0.742 \\
0.729 \\
0.709 \\
0.650 \\
\end{array}$ \\
\hline Organizational Effectiveness & $\begin{array}{l}\text { OE1 }<- \text { Organizational Effectiveness } \\
\text { OE2 }<\text { - Organizational Effectiveness } \\
\text { OE } 3<- \text { Organizational Effectiveness }\end{array}$ & $\begin{array}{l}0.764 \\
0.718 \\
0.777\end{array}$ \\
\hline
\end{tabular}

Table 4

CFA Model Fitness indices

\begin{tabular}{lccc}
\hline Fitness Indicators & Measurement Model & Structural Model & Threshold indices \\
\hline CMIN/DF & 3.000 & 2.440 & $<3$ \\
CFI & 0.931 & 0.983 & $<.90$ \\
SRMR & 0.051 & 0.053 & $<.06$ \\
RMSEA & 0.080 & 0.068 & $<.08$ \\
P-Value & 0.000 & 0.000 & $>.05$ \\
TLI & 0.913 & 0.968 & $>.90$ \\
NFI & 0.912 & 0.970 & $>.90$ \\
NNFI & 0.911 & 0.954 & $>.90$ \\
IFI & 0.950 & 0.989 & $>.95$ \\
GFI & 0.959 & 0.963 & $>.95$ \\
AGFI & 0.923 & 0.944 & $>.90$ \\
\hline
\end{tabular}

\section{Structural Model Test}

After the acceptance of the measurement model, we converted the measurement model into the structural model. The structural model is also a good fit and achieved the threshold indices of model fitness suggested by Hair et al. (2012) (see Table 4). After that, we computed the standardized path coefficients of the proposed structural model (see Table 5). As expected, talent management has a substantial effect on employee engagement $(\beta=.550, \mathrm{t}=10.688, \mathrm{p}=.000)$ and organizational performance $(\beta=.197, \mathrm{t}=3.477, \mathrm{p}=.000)$, thereby $\mathrm{H} 1 \mathrm{a}$ and $\mathrm{H} 1 \mathrm{~b}$ accepted. Similarly, career development has a direct significant effect on employee engagement $(\beta=.101, t=1.963, p=.050)$ and organizational performance 
$(\beta=.280, t=5.766, \mathrm{p}=.000)(\mathrm{H} 2 \mathrm{a} \& \mathrm{H} 2 \mathrm{~b}$ accepted $)$. Employee engagement $(\beta=.350, \mathrm{t}=6.439$, $\mathrm{p}=.000)$ has a positive and significant effect on organizational effectiveness (H3 accepted). To test the hypotheses of $\mathrm{H} 4$ and $\mathrm{H} 5$, we run the mediation analysis in AMOS by using the approach of bias-corrected boot strapping of Preacher and Hayes (2008). Table 5 shows the indirect effect of employee engagement at 95 percent confidence interval. Employee engagement (indirect effect=.192, $\mathrm{p}=.001$ ) significantly mediates the relationship between talent management and organizational effectiveness (H4 accepted). Similarly, employee engagement significantly (indirect effect $=.035, \mathrm{p}=.027$ ) mediates the relationship between career development and organizational effectiveness. Moreover, none of the control variable has a major effect on criterion construct (i.e., organizational effectiveness).

Table 5

The Findings of Hypotheses Testing

\begin{tabular}{|c|c|c|c|c|c|}
\hline Paths & Estimate & S.E & C.R (t) & p-value & Decision \\
\hline H1a: $\mathrm{TM} \rightarrow \mathrm{OE}$ & 0.197 & 0.053 & 3.477 & 0.000 & Accepted \\
\hline $\mathrm{H} 1 \mathrm{~b}: \mathrm{TM} \rightarrow \mathrm{EE}$ & 0.550 & 0.054 & 10.688 & 0.000 & Accepted \\
\hline $\mathrm{H} 2 \mathrm{a}: \mathrm{CD} \rightarrow \mathrm{OE}$ & 0.280 & 0.042 & 5.766 & 0.000 & Accepted \\
\hline $\mathrm{H} 2 \mathrm{~b}: \mathrm{CD} \rightarrow \mathrm{EE}$ & 0.101 & 0.050 & 1.963 & 0.050 & Accepted \\
\hline $\mathrm{H} 3: \mathrm{EE} \rightarrow \mathrm{OE}$ & 0.350 & 0.048 & 6.439 & 0.000 & Accepted \\
\hline Bootstrapping & Indirect effect & S.E & LB 95\% CI & UB 95\% CI P-Value & \\
\hline $\mathrm{H} 4: \mathrm{TM} \rightarrow \mathrm{EE} \rightarrow \mathrm{OE}$ & 0.192 & 0.038 & 0.122 & 0.268 .001 & Accepted \\
\hline $\mathrm{H} 5: \mathrm{CD} \rightarrow \mathrm{EE} \rightarrow \mathrm{OE}$ & 0.035 & 0.016 & 0.005 & 0.069 .0270 & Accepted \\
\hline
\end{tabular}

Figure 2

The Path Diagram

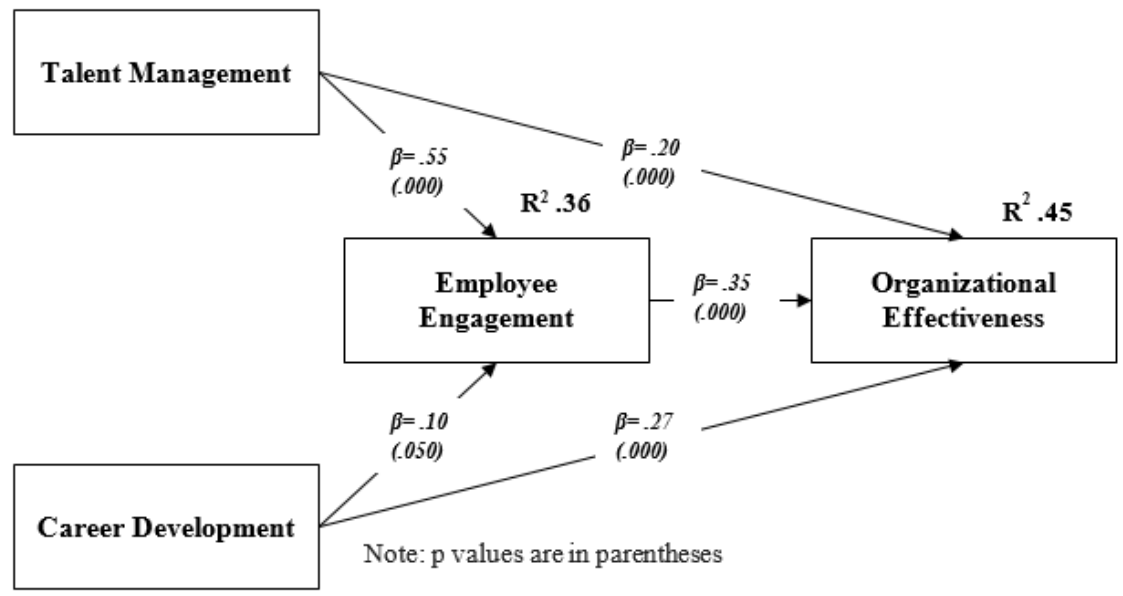

Figure 2 demonstrates the values of model prediction accuracy (R squares). The value of .36 illustrates that talent management and career development explain thirty-six percent 
of the variance in employee engagement. Similarly, the value of .45 illustrates that about forty-five percent of the variance has explained by all the predictors of study in criterion construct (i.e., organizational effectiveness). Thus, our study successfully explained the proposed structural relationships.

\section{Discussion}

The goal of this study was to investigate the influence of talent management and career development on organizational effectiveness and how employee engagement interpret the association between development factors (talent management and career development) and organizational effectiveness. As expected, the findings of our study proved that talent management and career development significantly related to organizational effectiveness. Moreover, employee engagement positively and significantly mediates the association between employee development factors and organizational effectiveness in the context of retail branch banking network. Overall, the current study tested the five hypotheses, and all are accepted.

The present study has reported that talent management has a significant effect on employee engagement and organizational effectiveness. This is consistent with the research work of Ifeoma et al. (2015); Guest (2014); Abbasi et al. (2010). Recently, Lyria et al. (2017) studied the relationship between talent management and organizational performance in Kenya and found that talent management creates a competitive edge which directly improves the company performance. Similarly, another study of Kimani and Waithaka (2013) conducted case studies in state-owned enterprises and identified the factors that improve the talent management practices which in turn increase organizational performance. Career development is positively and significantly related to employee engagement and organizational effectiveness. These findings are consistent with De Vos and Dries (2013); Saeed et al. (2013). They studied the career development as a motivating tool which engages the employees towards achieving best organizational performance. Jan (2010) studied the learning organizations and found that organizational support for career development engages the employees to perform their work efficiently in obtaining the superior organizational performance. The current study also supported that employee engagement mediates the relationships between employee development factors and organizational effectiveness. This is consistent with the research findings of Kular et al. (2008); Rama (2009). Finally, the current study successfully explained the phenomena which help the bank's managers to obtain better performance through implementing talent management practices including offering career development opportunities.

\section{Theoretical Implications}

First, the primary contribution of this paper is to empirically establish the relationship between development factors (talent management and career development) and organizational effectiveness in the context of commercial banks which was largely missed in the literature of employee development and organizational performance. Secondly, the present 
study extends the Deloitte Resource Model (DDC) while implementing talent management and offering career development opportunities (D: developing) and engaging (D: deploying and C: connecting) to improve the organizational performance. Previous studies mentioned the relationship between talent management and organizational success, but this work is the first to examine how talent management and career development generate organizational effectiveness with the help of employee engagement as a mediator. Third, the current study theoretically and empirically tested the mediation mechanism of employee engagement in the association between development factors and organizational effectiveness. Fourth, this study successfully retort to the future call for research made by Fornell and Larcker (1981); De Vos and Dries (2013); Lyria et al. (2017). We also addressed their studies limitations and extended their research on the topic of talent management.

\section{Practical Implications}

First, the present study guides the bank management to implement proactive talent generation strategies and motivate the employees of the bank by offering career development opportunities to achieve the best organizational goals. Such development opportunities will psychologically enhance their level of engagement. Secondly, this study offers the bank managers an outcome-oriented views how talent management strategies including career development enhance employee engagement level which in turn improves the organizational effectiveness. Third, organizations should provide training and development practices to their employees which retain the skilled employees and generates competitive advantage. Furthermore, organizations need to provide their employees with the resources that satisfy their needs and enhance efficacy to capitalize on the energy they bring to their role in the organization.

\section{Study Limitations and Future Research Directions}

The conducted study is subject to some limitations. First, the current study collected data from a large district of Pakistan which may result in low generalizability. Therefore, future studies can be done on the national or international level to replicate the results of this study. Secondly, we collected data from participants at a single point in time (crosssectional) which may produce common method bias, but our study did not indicate any bias in the sample set. Future studies should be done on longitudinal data collection to analyze the results over time. Furthermore, a fruitful line of future would be the addition of a new variable as a Moderating variable because the current study focused on mediation mechanism (employee engagement). The present study also focused on the service sector (banks), but the future studies should test the validity of our model on samples of employees from other organizations, occupations, and cultures. 


\section{References}

Abbasi, M. U., Sohail, M., \& Syed, N. (2010). Talent management as success factor for organizational performance: A case of pharmaceutical industry in Pakistan. IBT JournalL of Business Studies (JBS), 6(2), 74-83.

Adil, M. S. (2014). Impact of leader's change-promoting behavior on readiness for change: A mediating role of organizational culture. Journal of Management Sciences, 1(2), 102123.

Ali, Q., \& Brandl, J. (2017). Hrm research in Pakistan: Existing approaches and future directions. Journal of Management Sciences, 4(2), 170-192.

Ali, Z., \& Mehreen, A. (2018). Understanding succession planning as a combating strategy for turnover intentions. Journal of Advances in Management Research, 16(2). doi: 10 .1108/JAMR-09-2018-0076

Chuai, X., Preece, D., \& Iles, P. (2008). Is talent management just "old wine in new bottles"? The case of multinational companies in Beijing. Management Research News, 31(12), 901-911.

Deloitte, R. (2004). Talent management model, the develop-deploy-connect (DDC).

De Vos, A., \& Dries, N. (2013). Applying a talent management lens to career management: The role of human capital composition and continuity. The International Journal of Human Resource Management, 24(9), 1816-1831.

Fornell, C., \& Larcker, D. F. (1981). Evaluating structural equation models with unobservable variables and measurement error. Journal of Marketing Research, 18(1), 39-50.

Fred, L., \& Suzanne, J. P. (2002). Employee engagement and manager self-efficacy. The Journal of Management Development, 21(5), 376-387.

Garavan, T. N., Carbery, R., \& Rock, A. (2012). Mapping talent development: Definition, scope and architecture. European Journal of Training and Development, 36(1), 5-24.

Guest, D. (2014). Employee engagement: a sceptical analysis. Journal of Organizational Effectiveness: People and Performance, 1(2), 141-156.

Gupta, C. (2008). Human resource management, Sultan Chand E Sons. Educational Publishers, New Delhi.

Hair, J. F., Sarstedt, M., Ringle, C. M., \& Mena, J. A. (2012). An assessment of the use of partial least squares structural equation modeling in marketing research. Journal of the Academy of Marketing Science, 40(3), 414-433.

Ifeoma, O. R., Purity, N.-O., \& Okoye-Nebo, C. (2015). Effective talent management: Key to organisational success. Journal of Policy and Development Studies, 289(1850), 1-12.

Jan, Z. (2010). Career development in a learning organization (Unpublished doctoral dissertation). National University of Modern language (NUML) Islamabad.

Kahn, W. A. (1990). Psychological conditions of personal engagement and disengagement at work. Academy of Management Journal, 33(4), 692-724.

Kehinde, J. S. (2012). Talent management: Effect on organizational performance. Journal of Management Research, 4(2), 178-186.

Kimani, S. M., \& Waithaka, S. M. (2013). Factors affecting implimentation of talent management in state corporations: A case study of Kenya broadcasting corporation. International Journal of Business and Social Research, 3(4), 42-49. 
Kock, H., \& Ellström, P.-E. (2011). Formal and integrated strategies for competence development in SMEs. Journal of European Industrial Training, 35(1), 71-88.

Kular, S., Gatenby, M., Rees, C., Soane, E., \& Truss, K. (2008). Employee engagement: A literature review. Retrieved from https://eprints.kingston.ac.uk/4192/ $1 / 19$ wempen.pdf

Langley, P. R., Du, R., Toit, \& Herbst, D. L. (1992). Manual for the career development questionnaire. pretoria. Pretoria: Human Sciences Research Council.

Lent, R. W., \& Brown, S. D. (2006). On conceptualizing and assessing social cognitive constructs in career research: A measurement guide. Journal of Career Assessment, 14(1), 12-35.

Lockwood, N. R. (2006). Talent management: Driver for organizational success. HR Magazine, 51(6), 1-11.

Lyria, R. K., Namusonge, G., \& Karanja, K. (2017). Role of talent management on organisation performance in companies listed in Nairobi securities exchange in Kenya. Journal of Human Resource and Leadership, 1(3), 1-17.

Nilsson, S., \& Ellström, P.-E. (2012). Employability and talent management: Challenges for HRD practices. European Journal of Training and Development, 36(1), 26-45.

Pavlou, P. A., \& El Sawy, O. A. (2006). From it leveraging competence to competitive advantage in turbulent environments: The case of new product development. Information Systems Research, 17(3), 198-227.

Podsakoff, P. M., MacKenzie, S. B., Lee, J.-Y., \& Podsakoff, N. P. (2003). Common method biases in behavioral research: A critical review of the literature and recommended remedies. Journal of Applied Psychology, 88(5), 879-903.

Preacher, K. J., \& Hayes, A. F. (2008). Asymptotic and resampling strategies for assessing and comparing indirect effects in multiple mediator models. Behavior Research Methods, 40(3), 879-891.

Quinn, R. E., \& Rohrbaugh, J. (1981). A competing values approach to organizational effectiveness. Public Productivity Review, 5(2), 122-140.

Rama, D. V. (2009). Employee engagement is a two-way street. Human Resource Management International Digest, 17(2), 3-4.

Renee, B. B., \& Bradley, L. (2007). The impact of organisational support for career development on career satisfaction. Career Development Isnternational, 12(7), 617-636.

Rogelberg, S. G., \& Stanton, J. M. (2007). Introduction: Understanding and dealing with organizational survey nonresponse. Organizational Research Methods, 5(2), 122-140.

Romans, J., \& Lardner, L. (2005). Integrated talent management at BD Japan: How a holistic approach to talent management built a high performance culture. Strategic HR Review, 4(5), 16-19.

Saeed, R., Lodhi, R. N., Abbas, F., Ishfaque, U., Dustgeer, F., \& Ahmed, M. (2013). The organizational role in career development of employees. Management and Administrative Sciences Review, 2(6), 664-669.

Schaufeli, W. B., \& Bakker, A. B. (2004). Test manual for the utrecht work engagement scale. Unpublished manuscript, Utrecht University, the Netherlands.

Schweyer, A. (2010). Talent management systems: Best practices in technology solutions for recruitment, retention and workforce planning. New Jersey: John Wiley \& Sons. 
Sharma, S., Garg, B., \& Singh, K. (2012). Driving forces and emerging challenges in talent management: A pathway to organizational success. International Journal of Advanced Research in Computer Science and Software Engineering, 2(6), 117-121.

Zafar, J., Farooq, M., \& Quddoos, M. U. (2017). The relationship between protean career orientation and perceived employability: A study of private sector academics of Pakistan. Journal of Management Sciences, 4(2), 133-145.

Zheng, Y., \& Kleiner, B. H. (2001). Developments concerning career development and transition. Management Research News, 24(3/4), 33-39. 